\title{
Razlike v občutenju strahu pred kriminalom na javnih prostorih glede na spol: raziskava varne soseske $v$ Istanbulu
}

V velikih mestih je varnost pomemben dejavnik. Strah pred kriminalom pa je dejavnik, ki ni odvisen od dejanske stopnje kriminala, ampak je neposredno povezan $s$ kakovostjo prostora, ki vpliva na posameznikov občutek varnosti. Razlikuje se tudi glede na spol. V članku avtorici proučujeta strah pred kriminalom na javnih krajih na varnem območju velike metropole, pri čemer se osredotočata na to, kako na ta strah vplivajo prostorske značilnosti in kakšne so razlike med spoloma. Raziskava je bila leta 2017 izvedena v enem najvarnejših predelov Istanbula, ki ga tudi ženske dojemajo kot varnega. Vkl- jučevala je anketo, v kateri je sodelovalo 387 anketirancev in anketirank različnih starosti. Avtorici sta jih spraševali o strahu pred kriminalom na javnih krajih ter kdaj in zakaj ga občutijo. Izsledki so pokazali, da ženske tudi v varni soseski v mestu občutijo nekaj strahu ter da so med moškimi in ženskami pomembne razlike v tem, kako občutijo strah na javnih prostorih in $\mathrm{v}$ kakšnih okoliščinah.

Ključne besede: strah pred kriminalom, ocena tveganja, javni prostor, spol, Istanbul 


\section{Uvod}

V raziskavi avtorici proučujeta razlike med spoloma kot dejavnik, ki vpliva na občutenje strahu pred kriminalom na javnih mestih. Eden izmed pomembnih razlogov, zakaj se ženske izogibajo javnim prostorom, je prav strah pred kriminalom. Navedeno vpliva na ravnotežje med spoloma na javnih prostorih, zato je pomembno, da se ženske na njih počutijo varne in jih uporabljajo. Glavni cilj raziskave je ugotoviti, kako moški in ženske dojemajo varnost in kaj pri enih in drugih vzbuja strah pred kriminalom. Izsledki raziskave bi bili lahko podlaga za oblikovanje novih predpisov ali spremembo veljavne zakonodaje.

Eden glavnih razlogov za raziskavo je skrb vzbujajoče naraščanje nasilja nad ženskami v Turčiji v zadnjem desetletju. Število samomorov med ženskami, ki so med najbolj izstopajočimi posledicami tega nasilja, se je med letoma 2016 in 2018 povečalo za 30,6 \%, v zadnjih 15 letih pa kar za 428,9 \% (Tığll, 2019). Uradni podatki o kaznivih dejanjih nad ženskami v Turčiji niso javno dostopni, zato v raziskavo razen dostopnih podatkov o umorih ni bilo mogoče vključiti tovrstnih podatkov. Kot navaja Lordoğlu (2018), je v Turčiji stopnja prijav spolnih napadov in nadlegovanja precej nizka, definicija in meje spolnega nadlegovanja pa so v turški družbi zelo ohlapne, kar je treba upoštevati pri oceni kaznivih dejanj nad ženskami. V poročilu o nasilju nad ženskami v Turčiji (Karal in Aydemir, 2012) je izpostavljeno, da morda na strah žensk pred kriminalom bolj vpliva stopnja nasilja nad ženskami po vsej državi kot pa stopnja kriminala na posameznem območju. Moško nasilje je posledica patriarhalnega prepričanja, da je ženskino mesto doma. Posledično je nasilje prezrto in opravičljivo, zlasti tam, kjer je posredovanje uradnih organov nezadostno. Ženske se zato počutijo nemočne in ranljive. Čeprav morda dejansko niso žrtve, se po javnih mestnih prostorih ne morejo svobodno gibati. Zaradi novic o moških, ki na javnih mestih v Istanbulu napadajo ženske zaradi tega, kako so oblečene, in za to sploh niso primerno kaznovani, ženske na javnih prostorih občutijo čedalje večji strah. V članku avtorici proučujeta razlike pri občutenju strahu pred kriminalom na javnih mestih glede na spol, zlasti izbrane vidike navedenega strahu, in kako bi lahko težave rešili z ustrezno prostorsko ureditvijo.

\subsection{Pregled literature}

Strah pred kriminalom izhaja iz prepričanja, da je lahko nekdo žrtev kaznivega dejanja. Je čustven odziv, ki nastane zaradi občutka ogroženosti in tesnobe v povezavi z možnostjo nasilnega kaznivega dejanja (Covington in Taylor, 1991). Ko se pojavi, ga spremlja občutek ranljivosti zaradi nevarnosti fizične poškodbe (Garofalo, 1981; Ward idr., 1990). Navedeno se pogosto opisuje tudi kot občutek negotovosti, opredeljuje pa se tudi kot čustven odziv, za katerega je značilen občutek ogroženosti ali tesnobe, ki ga povzroča kriminal ali simboli, povezani s kriminalom (Ferraro in LaGrange, 1987). Posamezniki, ki jih je strah kriminala, se izogibajo nekaterim območjem (Ravenscroft idr., 2002), redkeje hodijo peš (Ross, 1993; Foster idr., 2010, so manj družabni (Ross in Jang, 2000) in spremenijo svoje navade (Garofalo, 1981). Ko posameznik samega sebe doživlja kot ogroženega, čeprav je objektivna verjetnost za to zelo majhna, lahko strah pred kriminalom postane resna težava. Tovrsten strah je osebni in tudi družbeni problem, ki slabša kakovost življenja, saj ljudem omejuje dostop do družabnih in kulturnih aktivnosti. Negativno vpliva na posameznikove odnose v družbi (Sacco, 1993). Zaradi svoje kompleksnosti postaja strah pred kriminalom družbeni in politični problem, ki obsega veliko več kot samo kriminal (Garofalo, 1981; Ferraro in LaGrange, 1992).

Strah pred kriminalom je čedalje pogostejša oblika strahu, zlasti med prebivalci večjih mest, močno pa je povezan s tem, kako posamezniki doživljajo svoje okolje in sebe v njem (Ferraro, 1995; Çardak, 2012). Posledično je strah pred kriminalom dejanski in zaznani problem. Kriminal in strah pred njim sta neposredno povezana s stopnjo izobrazbe, dohodkom, starostjo, etnično pripadnostjo, krajem bivanja, občutkom pripadnosti kraju in spolom (Gray idr., 2011). Glavni pristop k razlagi strahu pred kriminalom na podlagi posameznikovih lastnosti je pristop $z$ vidika ranljivosti, $v$ skladu $s$ katerim naj bi skupine, ki z vidika fizičnega, družbenogospodarskega in kulturnega položaja veljajo za šibkejše, bolj nemočne, manj zaščitene in ranljivejše zaradi zunanjih dejavnikov, pogosteje občutile strah pred kriminalom kot pa druge družbene skupine (Ferraro, 1995; Çardak, 2012; Kul, 2013). Ženske, stareǰ̌i, invalidi in posamezniki brez socialne podpore informacije, ki jih prejemajo iz okolice, intenzivneje dojemajo kot strah pred kriminalom (Covington in Taylor, 1991; Çardak, 2012).

Družbene skupine, ki so z vidika varnosti ranljivejše ali bolj prikrajš̌ne (tj. ženske, priseljenci, revni, LGBT osebe, invalidi, starejši, otroci in brezdomci), so večinoma predmet raziskav, ki se nanašajo na strah pred kriminalom (Covington in Taylor, 1991; Pain, 2001; Otis, 2007; Jackson, 2009). Nekatere raziskave niso pokazale pomembnih razlik na podlagi starosti, skoraj večina pa kaže, da je strah pred kriminalom pogostejši med ženskami kot moškimi (Valentine, 1989; MacMillan idr., 2000; Pain, 2001; Jackson, 2009; Uludağ, 2010; Kul, 2013; Öztürk idr., 2016). Jackson (2009) ugotavlja, da med kaznivimi dejanji nad osebami prevladujejo kazniva dejanja nad ženskami, pri kaznivih dejanjih zoper lastnino pa ni razlik med spoloma.

Čeprav sta kriminal in strah pred njim konceptualno povezana, je ta povezava šibka (Jackson, 2009; Dolu idr., 2010). Pri prou- 
čevanju strahu pred kriminalom je pomembno upoštevati tudi vpliv množičnih medijev in okolja. Ob tem je treba upoštevati tradicionalna prepričanja o ženskah, kar je podrobneje opisano v nadaljevanju. Čeprav je strah pred kriminalom povezan prav s kriminalom, se na neki točki spremeni v neodvisen dejavnik. To pojasni, zakaj se pojavlja tako med prebivalci mestnih predelov $\mathrm{z}$ visoko stopnjo kriminala kot med prebivalci varnejših mest ali mestnih predelov, kjer so stopnje kriminala nižje (Furstenberg, 1971; Ferraro, 1995).

\subsubsection{Strah pred kriminalom in spol}

Z vidika strahu pred kriminalom so ženske zagotovo najranljivejša družbena skupina. Strah med ženskami v zahodnem svetu se proučuje že od konca 20. stoletja (Valentine, 1989; Treske, 1990; Pain, 1991; Koskela, 1997), v Turčiji pa šele zadnjih deset let (Dolu, 2010; Çardak, 2012; Erkan, 2015; Yirmibeşoğlu in Ergun, 2015). Z vidika ranljivosti lahko pojasnimo tudi razlike med spoloma pri občutenju strahu pred kriminalom, saj je osebno dojemanje ranljivosti pomemben dejavnik, ki vpliva na posameznikov strah (Taylor in Hale, 1986; Franklin idr., 2008). Osebe, ki se počutijo fizično, socialno in gospodarsko nemočne, se bolj bojijo kriminala (Covington in Taylor, 1991; Hale, 1993), saj sebe dojemajo kot prešibke in preveč ranljive, da bi se lahko uprle morebitnim napadalcem, hkrati pa se vidijo kot potencialne žrtve raznih kaznivih dejanj. Ženske in starejši so zato ranljivejši kot odrasli moški in mladi ljudje. Raziskave kažejo, da se ženske (Warr, 1984; Hale, 1993; Mirrlees-Black idr., 1996; Sandberg in Rönnblom, 2013) in starejši (Warr, 1984; Ferraro in LaGrange, 1992; Jackson, 2009) bolj bojijo kriminala. Primerjave podatkov o žrtvah kažejo, da ženske (zlasti starejše) pogosteje občutijo strah pred kriminalom, čeprav so same redko žrtve. Mlajši moški pa se manj bojijo kriminala, čeprav je možnost, da tudi sami postanejo žrtve, večja (Hale, 1993). Opisanemu neskladju med strahom in dejansko viktimizacijo rečemo tudi paradoks med spolom in strahom.

Raziskave, ki temeljijo na razlikah med spoloma, vključno z raziskavo, predstavljeno v tem članku, kažejo, da ženske, ki živijo na mestnih območjih, pogosteje in močneje občutijo strah pred kriminalom kot moški, ki živijo na istih območjih (Valentine, 1989, 1992; Hale, 1993; Koskela, 1999; Pain, 1991, 2001; Dolu idr., 2010; Sandberg in Rönnblom, 2013; Uçan idr., 2016). Podatki o navedenem strahu kažejo, da so med stopnjami strahu, o katerih poročajo moški, in tistimi, o katerih poročajo ženske, razmeroma majhne, a statistično značilne razlike (Gilchrist idr., 1998). To pomeni, da je spol pomemben pokazatelj tovrstnega strahu.

Strah pred kriminalom na ženske vpliva na dva načina: izogibajo se nekaterim krajem in aktivnostim ter $s$ tem občutku strahu ali pa ponotranjijo predsodke in ideologije, ki škodu- jejo ženskam na splošno (Koskela, 1997; Sutton idr., 2011). $\mathrm{V}$ vsakem primeru je strah pred kriminalom mehanizem, ki ženske izžene iz posameznih mestnih prostorov in družbenih odnosov. Posledično se ženske zatečejo $\mathrm{k}$ izogibajočemu vedenju in si začnejo same omejevati življenje. Omejitve so lahko povezane s tem, kdaj odhajajo od doma in prihajajo domov, kam gredo, kako se oblačijo ter s kom govorijo in kako. Če je strah premočen, je njihovo življenje popolnoma omejeno (Valentine, 1989; Pain, 1991; Koskela, 1999; Çardak, 2012; Sandberg in Rönnblom, 2013; Tandoğan in Şimşek İlhan, 2016). Strah pred kriminalom ženskam zlasti omeji dostop do javnih prostorov in vpliva na njihovo obnašanje $\mathrm{v}$ javnosti. Ker se izogibajo javnim prostorom, se na teh prostorih poslabša tudi ravnovesje med spoloma, kar pri ženskah še dodatno povečuje strah pred temi prostori.

\subsubsection{Zunanji dejavniki, ki vplivajo na strah pred kriminalom}

Zmotno bi bilo misliti, da strah pred kriminalom izvira samo iz posameznikovega osebnega dojemanja. Številne raziskave se zato osredotočajo na zunanje dejavnike, kot so fizični prostor ali pa množični mediji, ki ustvarjajo občutek strahu. Posameznikov strah pred kriminalom se ne ujema $\mathrm{z}$ dejansko stopnjo kriminala, povezan pa je s poročanjem o kriminalu v množičnih medijih (Kohm idr., 2002; Smolej in Janne, 2006; Çardak, 2012; Sandberg in Rönnblom, 2013; Callanan in Rosenberger, 2015; Sallan Gül in Altındal, 2015).

Zaradi strahu začnejo biti ljudje pazljivi. Čeprav ni dejanske nevarnosti za nastanek kaznivega dejanja, novice o napadih, posilstvih in nasilju nad ženskami v množičnih medijih vplivajo na to, kako se ženske obnašajo v javnosti. Turška raziskava o strahu pred kriminalom med ženskami je razkrila, da polovica žensk na javnih prostorih občuti večji strah, če nosijo oblačila, $s$ katerimi telesa ne pokrijejo v celoti, ali če so same (Tandoğan in Şimşek İlhan, 2016). Ker so mediji začeli poročati o napadih na ženske v oblačilih, ki niso telesa pokrivala v celoti, čedalje več turških žensk občuti strah pred kriminalom (Internet 1 , Internet 2).

Zunanji dejavniki, ki vplivajo na strah pred kriminalom, niso omejeni samo na množične medije. Tudi nepravilnosti v grajenem okolju so lahko razlog za to, da se ljudje ne počutijo varne in se v njih prebudi strah pred kriminalom. Posameznike je strah tudi na temnih, opuščenih prostorih, s katerih se smeti ne odvažajo, območjih z vandaliziranimi objekti ali prostorih, na katerih razmerje med moškimi in ženskami ni uravnoteženo (Vrij in Winkel, 1991; Nasar in Fisher, 1993; Newman, 1996; Kalpana in Ashish, 2015). Zapuščene ulice, temni prehodi, nezadostna osvetljava, odročni mestni prostori in uporaba javnega prevoza v poznih urah so okoliščine, $\mathrm{v}$ katerih ljudje naj- 


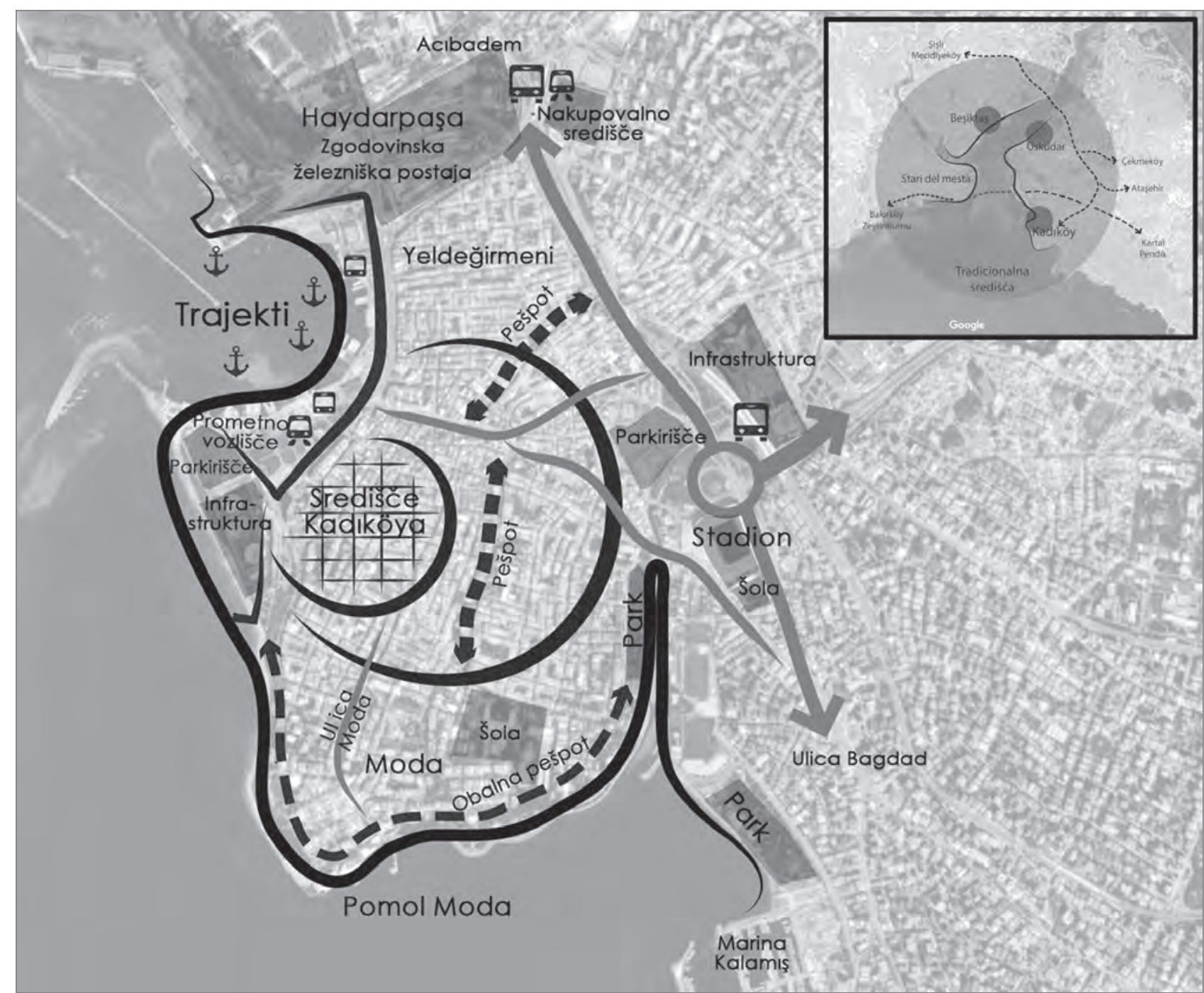

Slika 1: Lokacija soseske Kadıköy in tamkajšnja infrastruktura (ilustracija: G. E. Albayrak)

\section{Metode}

pogosteje občutijo strah pred kriminalom (Treske, 1990; Warr, 1990: Greene, 2003; Erkan 2015; Tandoğan in Şimşek İlhan, 2016). Kot navajajo Tandoğan in Şimşek İlhan (2016) ter Treske (1990), ženske pogosteje občutijo strah na neobljudenih območjih in kadar se stemni. Raziskava v Helsinkih pa je pokazala, da ženske dojemajo zimske in poletne večere kot enako nevarne, kljub razlikam v dolžini dneva. Četudi se pozimi prej stemni, je ob poletnih večerih zaradi prijaznejšega vremena na javnih mestih več moških (Koskela, 1998). Na podlagi navedene raziskave strah pri večini žensk ne izvira iz prostorskih značilnosti, ampak iz strahu pred moškimi (Valentine, 1989). Njihovega strahu pred kriminalom torej ne moremo preprosto odpraviti s prostorskimi izboljšavami (Koskela in Pain, 2000). Posledično ženske občutijo več strahu pred kriminalom kot moški, kar omejuje njihovo vključenost $\mathrm{v}$ javno življenje.

\subsection{Območje raziskave}

Kadıköy je soseska na azijski strani Istanbula (slika 1), za raziskavo pa je bil izbrana zato, ker velja za varen predel Istanbula, zlasti med ženskami, čeprav je precej oblegan in njegove javne prostore uporabljajo najrazličnejši ljudje (Bilen idr. 2013; Lordoğlu, 2018). Navedeno je pomemben podatek, saj sta se lahko avtorici osredotočili na strah pred kriminalom neodvisno od dejanske stopnje kriminala. Raziskava, ki jo je Lordoğlujeva opravila med samskimi ženskami (Lordoğlu, 2018), je pokazala še, da Kadıköy velja za ženskam najbolj prijazno stanovanjsko sosesko v Istanbulu.

Medijsko poročanje o napadih na ženske zaradi njihovih oblačil je julija 2017 sprožilo proteste na številnih območjih v Istanbulu, tudi v Kadıköyu. Organizirani protesti so bili po- 

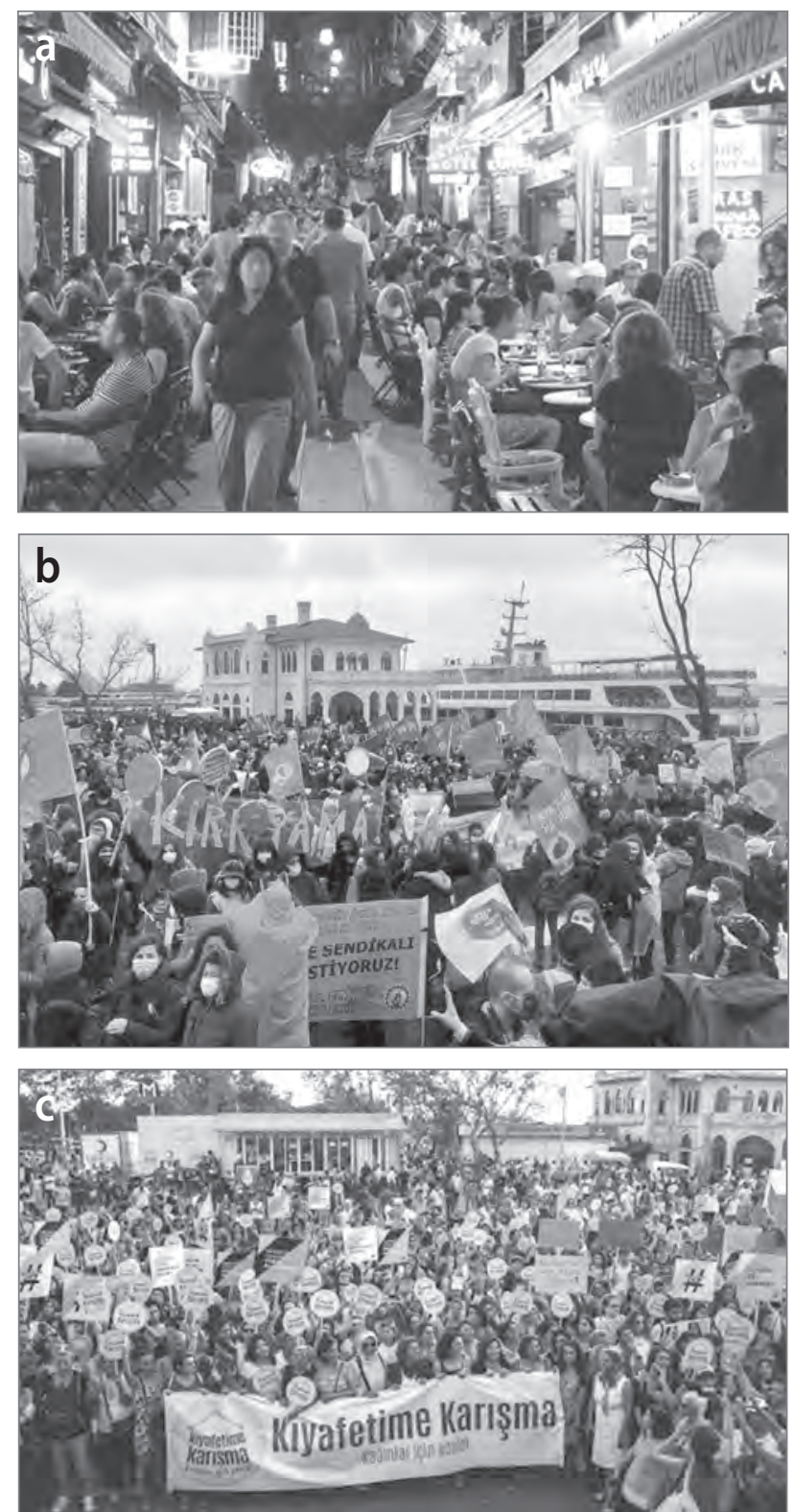

Slika 2: a) nočno življenje (foto: Internet 3), b) praznovanje ob dnevu žensk (foto: Internet 4), c) protest s sloganom: Pustite naša oblačila pri miru v Kadıköyu (foto: Internet 5)

sledica občutenja strahu pred kriminalom na javnih mestih. Eden izmed razlogov za izvedbo raziskave v Kadıköyu je bil tudi protest $s$ sloganom: Pustite naša oblačila pri miru. Zaradi zgoščenosti tako formalnih kot neformalnih družbenih organizacij v Kadıköyu se soseska z vidika družbenogospodarskih dejavnikov, kulture in nočnega življenja močno razlikuje od drugih območij v Istanbulu (slika 2).

$\mathrm{V}$ glavnem prostorskem načrtu mesta je Kadıköy opredeljen kot kulturno in prometno vozlišče, $\mathrm{v}$ zadnjih letih pa je postal še bolj obiskan in bolj kozmopolitski. Zaradi gostinskih lokalov ter raznih prostorov in površin za razvedrilo in zabavo so se okrepile tudi kulturne aktivnosti. Ker je območje dobro
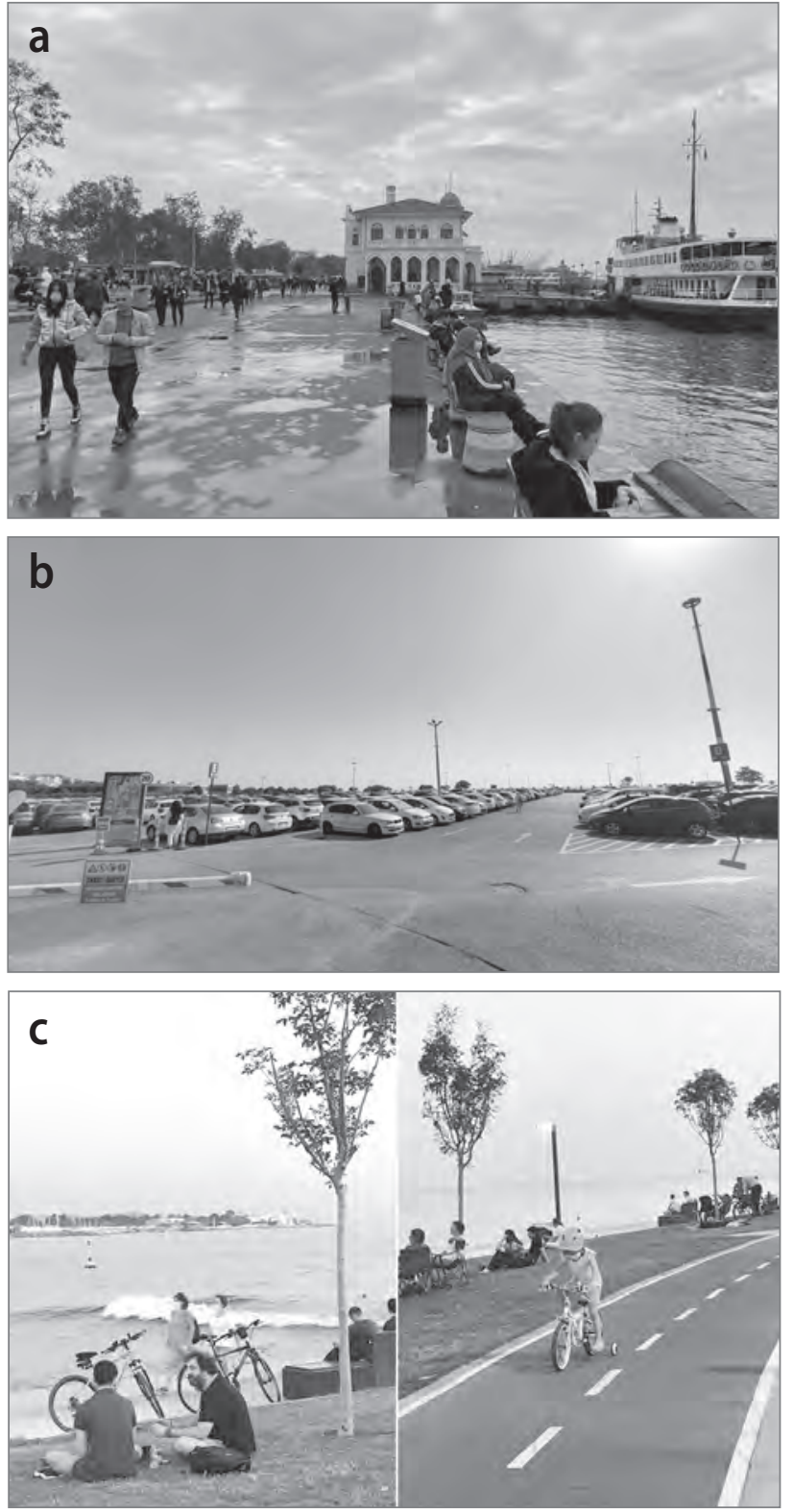

Slika 3: Različna prostorska raba nabrežja v Kadıköyu, a) pomoli (foto: N. Ç. Erkan), b) parkirišče (foto: B. Sevin), c) rekreacijsko območje (foto: F. Çobanoğlu)

dostopno $\mathrm{z}$ različnimi sredstvi javnega prevoza ( $\mathrm{s}$ trajektom, avtobusom, podzemno železnico itd.), je tam čedalje več turistov, gneča je vse večja, območje pa je živahno še pozno v noč. Po podatkih turškega statističnega inštituta je leta 2017 v Kadıköyu živelo 451.453 ljudi, dnevno pa ga je obiskalo več kot šestkrat toliko turistov (Kadıköy District Registry Office, 2017). Območje raziskave je obsegalo tradicionalno tržnico (ki ima največ obiskovalcev), nakupovalna območja, površine za zabavo, nabrežje, ki je hkrati prometno vozlišče in rekreacijsko območje, in multimodalno prometno vozlišče na celini (sliki 3 in 4). Avtorici sta območje opazovali ob različnih dnevih in različnih časih, hkrati pa sta na njem izvedli tudi anketo, opisano v nadaljevanju. 

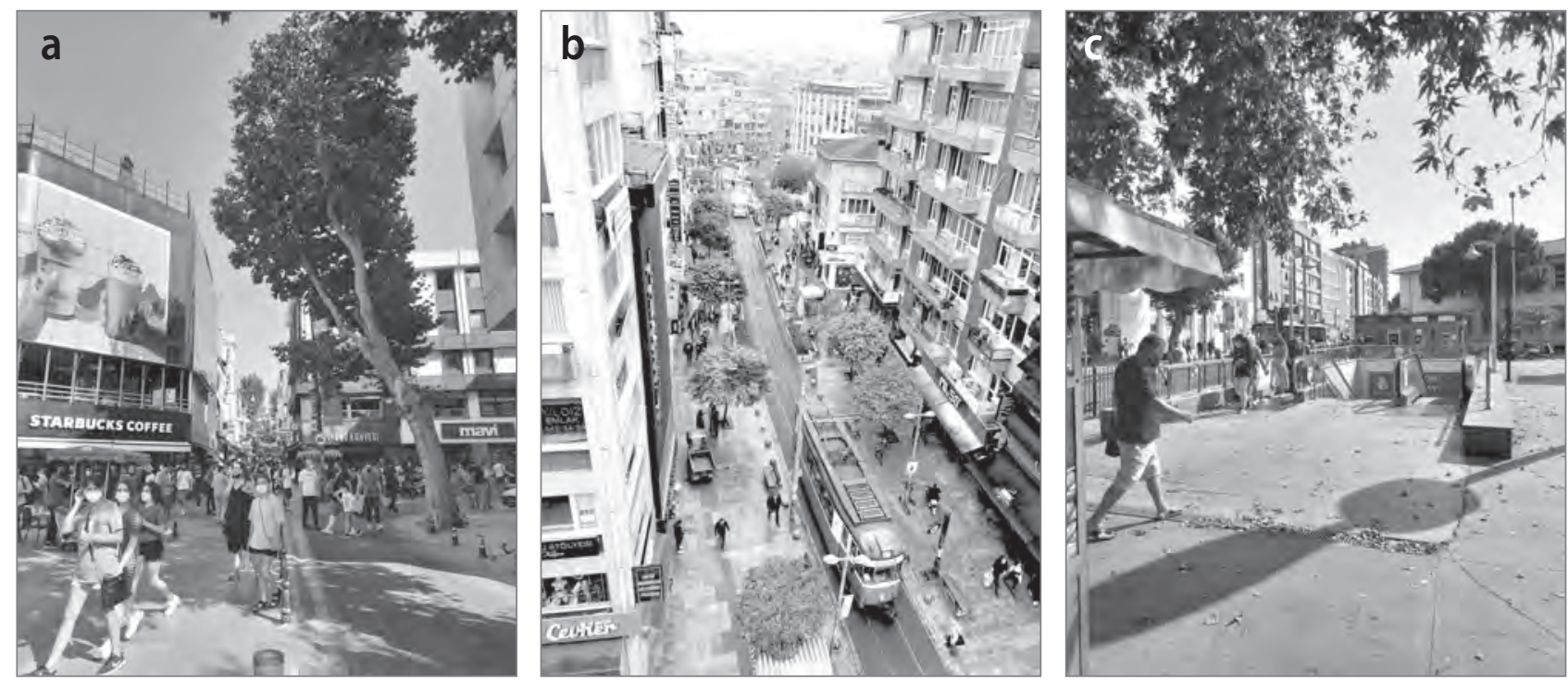

Slika 4: a) Ljudje na nakupovalnem območju (foto: B. Sevin), b) cona za pešce s trgovinami (foto: N. Ç. Erkan), c) postaja podzemne železnice (foto: B. Sevin)

\subsection{Anketa}

Raziskava se osredotoča na strah pred kriminalom, ki ga občutijo uporabniki varnih javnih prostorov, in z njim povezane razlike med ženskami in moškimi. Avtorici sta proučevali, na katerih krajih ljudje občutijo strah in katere okoliščine lahko vzbujajo ta strah. Oblikovali sta ta raziskovalna vprašanja: 1 . Ali v varnem mestnem predelu moški in ženske različno občutijo strah pred kriminalom? 2. Ali kakovost javnega prostora in okoliščine na njem vplivajo na strah pred kriminalom? 3. Ali so pri doživljanju strahu pred kriminalom na proučevanem javnem prostoru - ob upoštevanju njegove kakovosti in okolišcin na njem - razlike med spoloma? Na podlagi navedenih vprašanj in izhodišča raziskave sta postavili hipotezo, da ženske občutijo več strahu pred kriminalom na javnih prostorih kot moški, ne glede na to, kako varno je območje.

Na proučevanem območju sta avtorici izvedli poglobljeno anketo, $s$ katero sta zbrali podatke o izkušnjah in razmišljanju uporabnikov tamkajšnjih javnih prostorov. Vprašanja so bila razdeljena v tri sklope: a) vprašanja, pri katerih so uporabniki navedli svoje osebne podatke (spol, starost in stopnjo izobrazbe), razloge za obisk Kadıköya in kako pogosto ga obiščejo, b) vprašanja o tem, ali se v Kadıköyu počutijo varne in na katerih krajih občutijo strah, c) vprašanja o tem, kateri kraji in okolišcine bi lahko v njih vzbudili strah. Pri tretjem sklopu vprašanj so anketiranci izpostavili $15 \mathrm{krajev}$ in 9 okolišcin, ki bi bili lahko problematični. Kraje in okoliščine so morali ovrednotiti na petstopenjski Likertovi lestvici ( 1 - sploh se ne strinjam, 5 - popolnoma se strinjam), pri čemer so lahko ocenili poljubno število navedenih možnosti.
Avtorici sta omenjene kraje in okoliščine izbrali na podlagi rezultatov pilotne raziskave iz leta 2014, v kateri je sodelovalo 60 žensk, ki so izpostavile več lokacij, ki jim vzbujajo strah. Med njimi so zlasti temni in opuščeni kraji, kjer je vidljivost slaba, in kraji, kjer je gneča in morebitni storilci ostanejo neopaženi. $V$ anketo sta avtorici vključili tudi stranske in glavne ulice, vendar so z vidika strahu pred kriminalom manj pomembne. Izbrane lokacije sta opisali z njihovimi funkcijami in nista dejansko navedli imen posameznih sosesk na proučevanem območju. Pričakovali sta, da bosta med njimi ugotovili statistično značilne razlike. V vprašalnik sta v razdelek z naslovom Okoliščine vključili tudi situacije, ki se lahko pojavijo na katerem koli kraju (npr. gneča, neobljudena območja, tema, prisotnost potepuških živali, beračev, narkomanov in podobno, situacije, v katerih se posameznik izgubi na nekem območju, ga besedno nadleguje neznana oseba ali več ljudi strmi vanj, ali ko večja skupina ljudi povzroča hrup itd.). Strah pred kriminalom glede na spol je bila odvisna spremenljivka, javni kraji s svojimi značilnostmi in okoliščinami pa so bili neodvisne spremenljivke.

Anketa se je izvajala v maju in juniju 2017. V njej je sodelovalo 387 oseb, in sicer 170 prek spleta in 217 z osebnimi srečanji. Pred statističnimi analizami, na podlagi katerih sta avtorici ugotavljali, ali so podatki normalno porazdeljeni, sta veljavnost pridobljenih podatkov preverili z analizo koeficientov asimetrije in sploščenosti. Ker so bile vrednosti omenjenih koeficientov med -2 in +2 , so bili podatki normalno porazdeljeni (George in Mallery, 2010). Glede na to, da so bili podatki pridobljeni prek osebnih in spletnih anket, sta podobnost njune porazdelitve preverili z Wald-Wolfowitzem testom sekvenc, ki je pokazal, da so podatki, pridobljeni od obeh skupin anketirancev, podobno porazdeljeni. Spletno anketo sta avtorici uporabili 
Preglednica 1: Spol in izobrazba anketirancev ter razlogi, zakaj so v Kadıköyu

\begin{tabular}{|c|c|c|c|c|}
\hline Merilo in vrednost & & Ženske: $n$ (v \%) & Moški: $n$ (v \%) & Skupaj: $n$ (v \%) \\
\hline \multirow{7}{*}{ Starost (v letih) } & $15-25$ & $63(27)$ & $35(23)$ & $98(25)$ \\
\hline & $26-35$ & $91(38)$ & $62(41)$ & $153(40)$ \\
\hline & $36-45$ & $51(22)$ & $24(16)$ & $75(19)$ \\
\hline & $46-55$ & $17(79)$ & $11(7)$ & $28(7)$ \\
\hline & $56-65$ & $9(6)$ & $13(9)$ & $22(6)$ \\
\hline & $65+$ & $6(14)$ & $5(24)$ & $11(17)$ \\
\hline & Skupaj & $237(100)$ & $150(100)$ & $387(100)$ \\
\hline \multirow{6}{*}{ Raven izobrazbe } & Osnovna šola & $7(3)$ & $6(4)$ & $13(3)$ \\
\hline & Srednja poklicna šola & $5(2)$ & $7(5)$ & $12(3)$ \\
\hline & Gimnazija & $38(16)$ & $20(13)$ & $58(15)$ \\
\hline & Univerzitetna diploma & $143(60)$ & $96(64)$ & $239(62)$ \\
\hline & Magisterij, doktorat & $44(19)$ & $21(14)$ & $65(17)$ \\
\hline & Skupaj & $237(100)$ & $150(100)$ & $387(100)$ \\
\hline \multirow{3}{*}{ Razlogi } & Tam živijo in delajo & $65(27)$ & $55(37)$ & $120(31)$ \\
\hline & Drugo & $172(73)$ & $95(63)$ & $267(69)$ \\
\hline & Skupaj & $237(100)$ & $150(100)$ & $387(100)$ \\
\hline Skupaj & & $237(61,2)$ & $150(38,8)$ & $387(100)$ \\
\hline
\end{tabular}

Preglednica 2: Hi-kvadrat analiza odvisnosti med spolom in občutkom varnosti

\begin{tabular}{|c|c|c|c|c|c|c|c|}
\hline & & \multicolumn{2}{|c|}{ Spol } & \multirow[t]{2}{*}{ Skupaj } & \multirow[t]{2}{*}{$x^{2}$} & \multirow[t]{2}{*}{$S D$} & \multirow[t]{2}{*}{$p$} \\
\hline & & Ženski & Moški & & & & \\
\hline $\begin{array}{l}\text { Je v Kadıköyu kakšen kraj, na katerem se ne } \\
\text { počutite varni? }\end{array}$ & $\mathrm{Ne}$ & 123 & 101 & 224 & 8,976 & 1 & ,003 \\
\hline & $\mathrm{Da}$ & 114 & 49 & 163 & & & \\
\hline Skupaj & & 237 & 150 & 387 & & & \\
\hline
\end{tabular}

zato, da bi lahko v raziskavo vključili osebe, ki nimajo časa odgovarjati na vprašanja na ulici, mlajše generacije, ki so spretne $z$ uporabo družbenih medijev, in posameznike, ki se zaradi strahu pred kriminalom izogibajo sporazumevanju z neznanci. Spletne vprašalnike sta tako prek družbenih medijev poslali posameznikom, ki so kakor koli povezani s Kadıköyem (tam živijo, delajo ali ga obiskujejo). Osebne ankete sta izvajali pripravnici. Uporabljena je bila metoda neverjetnostnega priložnostnega vzorčenja, ankete pa so bile opravljene z naključnimi osebami na javnih prostorih v Kadıköyu, in sicer med tednom in tudi ob koncu tedna. $\mathrm{V}$ anketi je sodelovalo več žensk ( $n=$ 237) kot moških $(n=150)$. Razlog je ta, da so ženske bolj pripravljene sodelovati v anketah kot moški in da moški redkeje govorijo o svojih strahovih (Crawford idr., 1990; Jackson, 2009: 371, 381).

Iz preglednice 1 je razvidno, da je imelo $79 \%$ anketirancev vsaj univerzitetno izobrazbo. To pomeni, da so prebivalci ali obiskovalci soseske visoko izobraženi. Posamezniki z višjo stopnjo izobrazbe so bili tudi bolj pripravljeni sodelovati v anketi. Med anketiranci jih je 31 \% živelo ali delalo v Kadıköyu, 69 \% pa jih je sosesko obiskalo zaradi različnih razlogov (preglednica 1).
Preglednica 3: Povezava med kraji, ki ljudem vzbujajo strah, in spolom

\begin{tabular}{lll}
\hline Kraji & $r$ & $p$ \\
\hline Sredstva javnega prevoza &,$- 209^{* *}$ &, 000 \\
\hline Avtobusne postaje &,$- 181^{* *}$ &, 000 \\
\hline Postaje podzemne železnice &,$- 188^{* *}$ &, 000 \\
\hline Podhodi &,$- 232^{* *}$ &, 000 \\
\hline Stanovanjska območja &,$- 278^{* *}$ &, 000 \\
\hline Tržnica ponoči &,$- 175^{* *}$ &, 001 \\
\hline Nabrežje ponoči &,$- 280^{* *}$ &, 000 \\
\hline Park &,$- 215^{* *}$ &, 000 \\
\hline Parkirišče &,$- 288^{* *}$ &, 000 \\
\hline Notranje parkirišče &,$- 395^{* *}$ &, 000 \\
\hline Območja, porisana z grafiti &,$- 115^{*}$ &, 023 \\
\hline Stranske ulice &,$- 177^{* *}$ &, 000 \\
\hline Glavne ulice &,$- 200^{* *}$ &, 000 \\
\hline Blizu lokalov, kjer strežejo alkoholne &,$- 273^{* *}$ &, 000 \\
pijače &,$- 175^{* *}$ &, 001 \\
\hline Blizu opuščenih in praznih območij & &
\end{tabular}

Opomba: ${ }^{*} p<0,05,{ }^{* *} p<0,01$. 
Preglednica 4: Regresijska analiza krajev, ki ljudem vzbujajo strah, glede na spol

\begin{tabular}{llllll}
\hline Odvisna spremenljivka & Pril. $R^{2}$ & $F($ znač. $)$ & $\beta$ & $t$ (znač.) & Velikost vpliva \\
\hline Sredstva javnega prevoza &, 041 & $17,551(, 000)$ &,- 209 & $-4,189(, 000)$ & Majhen \\
\hline Avtobusne postaje &, 030 & $12,977(, 000)$ &,- 181 & $-3,602(, 000)$ & Majhen \\
\hline Postaje podzemne železnice &, 033 & $20,499(, 000)$ &,- 188 & $-3,755(, 000)$ & Majhen \\
\hline Podhodi &, 072 & $31,039(, 000)$ &,- 273 & $-5,571(, 000)$ & Majhen \\
\hline Stanovanjska območja &, 028 & $12,134(, 001)$ &,- 175 & $-3,483(, 001)$ & Majhen \\
\hline Tržnica ponoči &, 037 & $15,984(, 000)$ &,- 200 & $-3,998(, 000)$ & Majhen \\
\hline Nabrežje ponoči &, 051 & $21,807(, 000)$ &,- 232 & $-4,670(, 000)$ & Majhen \\
\hline Stranske ulice &, 075 & $32,264(, 000)$ &,- 278 & $-5,680(, 000)$ & Majhen \\
\hline Glavne ulice &, 028 & $12,097(, 001)$ &,- 175 & $-3,478(, 001)$ & Majhen \\
\hline Park &, 076 & $32,859(, 000)$ &,- 280 & $-5,732(, 000)$ & Majhen \\
\hline Blizu lokalov, ki strežejo alkoholne pijače &, 044 & $18,610(, 000)$ &,- 215 & $-4,314(, 000)$ & Majhen \\
\hline Parkirišče &, 081 & $34,862(, 000)$ &,- 288 & $-5,904(, 000)$ & Majhen \\
\hline Notranje parkirǐ̌če &, 154 & $71,313(, 000)$ &,- 395 & $-8,445(, 000)$ & Srednji \\
\hline Kraji, porisani z grafiti &, 011 & $5,197(, 023)$ &,- 115 & $-2,280(, 023)$ & Majhen \\
\hline Blizu opuščenih in praznih območij &, 029 & $12,404(, 000)$ &,- 177 & $-3,522(, 000)$ & Majhen \\
\hline
\end{tabular}

Preglednica 5: Korelacija med okoliščinami, ki vzbujajo strah, in spolom

\begin{tabular}{lll}
\hline Okoliščine & $r$ & $p$ \\
\hline Izgubiš se &,$- 206^{* *}$ &, 000 \\
\hline Gneča &,- 070 &, 167 \\
\hline Opuččena območja &,$- 348^{* *}$ &, 000 \\
\hline Tema &,$- 416^{* *}$ &, 000 \\
\hline Berači, narkomani itd. &,$- 253^{* *}$ &, 000 \\
\hline Besedno nadlegovanje &,$- 427^{* *}$ &, 000 \\
\hline Prisotnost potepuških živali &,- 094 &, 064 \\
\hline Večja skupina strmi vate &,$- 279^{* *}$ &, 000 \\
\hline Skupina povzroča hrup &,- 091 &, 073 \\
\hline
\end{tabular}

Opomba: ${ }^{*} p<0,05,{ }^{* *} p<0,01$.

\section{Rezultati}

V raziskavi sta avtorici proučevali, ali se ženske in moški v Kadiköyu počutijo varne. $S$ hi-kvadrat testom sta ugotavljali, ali je občutek varnosti odvisen od spola, odvisnost med spremenljivkama pa se je izkazala za statistično značilno $\left(\chi^{2}=8,97\right.$; $p<, 05$; preglednica 2).

Pri izračunu povezave med kraji, ki vzbujajo strah, in spolom so bili vsi rezultati negativni in statistično značilni $(p<0,05$; preglednica 3).

Pri regresijski analizi spremenljivke »spol « sta avtorici uporabili enostavno kodiranje, in sicer sta ženskemu spolu pripisali vrednost 0 , moškemu pa 1 . To pomeni, da ima moški spol negativen vpliv in da moški dosegajo nižje vrednosti pri vprašanjih o krajih, ki vzbujajo strah. Regresijska analiza je pokaza- la, da neodvisna spremenljivka »spol « pomembno pojasnjuje vse spremenljivke, povezane $s$ kraji. Med njimi je bil največji vpliv ugotovljen pri spremenljivki $\gg$ notranje parkirišče $\ll\left(R^{2}=\right.$ ,154, $F(1,385)=71,31, p<, 001)$, ki jo spremenljivka $\gg$ spol $\ll$ tudi najbolj pojasnjuje $(\beta=-, 395, t(385)=-8,445, p<, 001$; preglednica 4).

Pri korelacijski analizi povezava med spolom in gnečo, prisotnostjo potepuških živali in skupino, ki povzroča hrup, ni bila statistično značilna $(p>0,05)$, zato navedene spremenljivke niso bile vključene v regresijsko analizo (preglednica 5).

Pri regresijski analizi sta avtorici za ugotavljanje vpliva moškega spola uporabili enostavno kodiranje (ženski spol $=0$, moški spol =1). Rezultati regresijske analize so pokazali, da ima moški spol negativen vpliv (preglednica 6), kar pomeni, da ženske dosegajo višje vrednosti pri vprašanjih glede okoliščin, ki vzbujajo strah. Neodvisna spremenljivka »spol « je pomembno pojasnila vse druge spremenljivke. Velikost vpliva pri spremenljivkah »opuščena območja « $\left(R^{2}=, 040, F(1\right.$, $385)=17,07, p<, 001), \gg$ tema $\ll\left(R^{2}=, 171, F(1,385)=\right.$ $80,73, p<, 001)$ in $\gg$ besedno nadlegovanje $\ll\left(R^{2}=, 181, F(1\right.$, $385)=86,08, p<, 001)$ pa je večja kot pri drugih spremenljivkah. Regresijska analiza ni bila opravljena, saj med prisotnostjo potepuških živali, skupino, ki povzroča hrup, in gnečo ni statistično značilne povezave.

Analize so pokazale, da je spremenljivka »spol « negativno in statistično značilno povezana $\mathrm{z}$ vsakim krajem in okoliščino. Moški spol ima pri teh okoliščinah negativen vpliv, zaradi česar so pri moških tudi vrednosti, povezane z občutenjem strahu, nižje. Spremenljivka »spol« najbolje pojasni besedno nadle- 
Preglednica 6: Regresijska analiza okoliščin, ki vzbujajo strah, glede na spol

\begin{tabular}{llllll}
\hline Odvisna spremenljivka & Pril. $R^{2}$ & $F($ znač. $)$ & $\beta$ & $t$ (znač.) & Velikost vpliva \\
\hline Izgubiš se &, 040 & $17,071(, 000)$ &,- 206 & $-4,132(, 000)$ & Majhen \\
\hline Opuščena območja &, 119 & $52,919(, 000)$ &,- 348 & $-7,275(, 000)$ & Majhen do srednji \\
\hline Tema &, 171 & $80,736(, 000)$ &,- 416 & $-8,985(, 000)$ & Srednji \\
\hline Berači, narkomani itd. &, 061 & $26,258(, 000)$ &,- 253 & $-5,124(, 000)$ & Majhen \\
\hline Besedno nadlegovanje &, 181 & $86,084(, 000)$ &,- 427 & $-9,278(, 000)$ & Srednji \\
\hline Večja skupina strmi vate &, 076 & $32,566(, 000)$ &,- 279 & $-5,707(, 000)$ & Majhen \\
\hline
\end{tabular}

govanje, kar pomeni, da se ženske tega bojijo bolj kot katere koli druge okoliščine.

\section{Razprava}

V raziskavi sta avtorici proučevali povezavo med spolom ter kraji in okoliščinami, ki vzbujajo strah pred kriminalom na javnih mestih. Rezultati kažejo, da čeprav javni prostor velja za varnega, ženske nad njem občutijo več strahu kot moški, ne glede na okoliščine. $V$ neki drugi raziskavi, opravljeni $\mathrm{v}$ Istanbulu, je $79 \%$ anketirancev navedlo, da se na javnih prostorih ne morejo svobodno in varno gibati, ker se bojijo, da bodo napadeni (Kul, 2013: 86; Karasu, 2017: 63). Rezultati raziskave, predstavljene v tem članku, pa kažejo, da se $42,1 \%$ anketirancev ne počuti varne na nekaterih krajih v Kadıköyu. Na podlagi navedenih podatkov je Kadıköy varnejši od preostalega metropolitanskega območja Istanbula. Po drugi strani je $70 \%$ anketirancev, ki se tam ne počutijo varne, žensk, kar pomeni, da se ženske počutijo bolj ogrožene kot moški. Na podlagi poročila turškega statističnega inštituta o zadovoljstvu z življenjem (TÜíK, 2016) je bil delež ljudi, ki se ne počutijo varne, ko se v svoji soseski ponoči sprehajajo sami, 26,2\% (med moškimi je bil ta delež $15,2 \%$, med ženskami pa $37 \%$ ). Varne se je na območju, na katerem živijo, počutilo $71 \%$ moških in $47,5 \%$ žensk. Iz navedenih podatkov je razvidno, da se ženske počutijo manj varne kot moški. Izsledki raziskave torej kažejo, da je med spolom in občutkom varnosti statistično značilna povezava in da se ženske pogosteje počutijo ogrožene.

Avtorici sta proučevali tudi vpliv značilnosti javnih prostorov in okoliščin na teh prostorih na občutek strahu pred kriminalom. Ugotovili sta, da na strah na primer vplivata opustelost in tema. Izsledki so pokazali tudi protislovje v zvezi z opuščenimi kraji. Glede strahu na opuščenih območjih ni bilo razlik med moškimi in ženskami, je pa regresijska analiza pri spremenljivki »opuščena območja « pokazala majhen do srednje velik vpliv. Izračunana $p$-vrednost za spremenljivko »opuščena območja « je znašala 0,073 , kar pomeni, da je povezava delno statistično značilna. Če bi v anketi sodelovalo več ljudi, bi morda navedena vrednost dosegla statistično značilno raven (Pritschet idr., 2016). Izsledki torej kažejo, da kraji, kot so notranja parkirišča in opuščena območja, vzbujajo strah in da se ženske bolj kot moški bojijo teme in besednega nadlegovanja. Raziskava, opravljena med ženskami v Istanbulu, je pokazala, da se ženske najbolj bojijo fizičnega nadlegovanja $(42 \%)$ in temnih ulic $(11,4 \%)$, strah pa jih je tudi napadov $(9,24 \%)$ na javnih prostorih (Erkan, 2015). Tandoğanova in Şimşek İlhanova (2016) sta proučevali strah pred kriminalom med prebivalkami mest, pri čemer sta ugotovili, da se $88,0 \%$ žensk, vključenih v raziskavo, na opuščnih ali tihih ulicah in cestah ponoči ni počutilo varno. Navedeno se ujema z rezultati raziskave, predstavljene v tem članku.

Raziskave kažejo, da nekateri strahovi (npr. strah pred besednim nadlegovanjem) bolj vplivajo na obnašanje žensk na javnih prostorih kot drugi. Tandoğanova in Şimşek İlhanova (2016) ugotavljata, da ženske v Istanbulu pogosto besedno nadlegujejo neznanci $(63,4 \%)$. V intervjujih, opravljenih v okviru raziskave, predstavljene v tem članku, so nekatere študentke navedle, da nosijo slušalke, ko so same, da ne slišijo zmerljivk ali se vsaj pretvarjajo, da jih ne slišijo. Vćasih je lahko tudi strmenje na javnih mestih ravno tako žaljivo kot besedno nadlegovanje, saj vpliva na obnašanje žensk. Ker je v družbi, kjer imajo glavno besedo moški, zelo težko jasno določiti meje med tem, kaj je nadlegovanje in kaj ne (čeprav sta strmenje in besedno nadlegovanje za ženske v nekaterih primerih nekaj samoumevnega), tovrstni dejavniki pri ženskah še naprej vzbujajo strah.

\section{Sklep}

Čeprav se ženske v Kadıköyu počutijo varnejše in svobodnejše kot $\mathrm{v}$ drugih predelih Istanbula, še vedno občutijo strah pred kriminalom. Kot je razvidno iz podobnih raziskav, spol pomembno vpliva na občutek strahu pred kriminalom na javnih prostorih. Urbanistične ureditve lahko pomagajo pregnati strah pred kriminalom na javnih prostorih, vendar raziskave kažejo, da to ni dovolj. Rezultati raziskave potrjujejo, da bi bilo treba uvesti nekatere družbene varnostne ukrepe, zlasti za preprečevanje strahu pred kriminalom med ženskami.

Omeniti je treba, da ima raziskava, predstavljena v tem članku, nekatere omejitve. Posamezniki, ki so prostovoljno sodelovali v anketi, imajo višjo stopnjo izobrazbe kot povprečen prebivalec Istanbula, zato njenih izsledkov ni mogoče posplošiti na ce- 
lotno mesto. V naslednji fazi raziskave bi bilo treba primerjati strah pred kriminalom $\mathrm{v}$ varnem in nevarnem mestnem predelu ter proučiti razlike v občutenju strahu na obeh območjih glede na spol.

Nilgün Çolpan Erkan

Tehnična univerza Yıldız, Fakulteta za arhitekturo, Oddelek za urbanizem in regionalno načrtovanje, Istanbul, Turčija

E-naslov: nilgunerkan@gmail.com

Beril Sevin Topçu

Občina Kadıköy, Istanbul, Turčija

E-naslov: berilsevin@gmail.com

\section{Zahvala}

Avtorici se zahvaljujeta Kağanu Güneyu za pomoč pri statistični obdelavi podatkov ter Meryem Çağış in Ebru Çakmak za pomoč pri izvedbi terenske ankete.

\section{Viri in literatura}

Bilen, Ö., Aşkın, Ö. E., Büyüklü, A. H., Ökten, A., in Mehmet, G. Ü. R. (2013): How the fear of crime spatially differs among the districts of Istanbul? Social Sciences, 8(4), str. 153-164.

DOI: 10.12739/NWSA.2013.8.4.3C0115

Callanan, V., in Rosenberger, J. S. (2015): Media, gender, and fear of crime. Criminal Justice Review, 40(3), str. 322-339. DOI: $10.1177 / 0734016815573308$

Çardak, B. (2012): Kadınların Suç Korkuları Üzerine Nitel Bir Çalışma Güvenlik Bilimleri Dergisi, 1(1), str. 23-45. DOI: 10.28956/gbd.239715

Covington, J., in Taylor, R. (1991): Fear of crime in urban residential neighborhoods: Implications of between- and within-neighborhood sources for current models. The Sociological Quarterly, 32(2), str. 231249. DOI: $10.1111 /$ j.1533-8525.1991.tb00355.x

Crawford, A., Jones, T., Woodhouse, T., in Young, J. (1990): The second Islington crime survey. London, Centre for Criminology, Middlesex Polytechnic.

Dolu, O., Uludağ, Ş., in Doğutaş, C. (2010): Suç Korkusu: Nedenleri, Sonuçları ve Güvenlik Politikaları İlişkisi. Ankara Üniversitesi SBF Dergisi. 65(1), str. 58-81. DOI: 10.1501/SBFder_0000002154

Erkan, N. Ç. (2015). Büyük Kentlerde Kadınların Korku Mekanları. V: Solak, A., in Solak, Ö. (ur.): Gündelik Hayat Sosyolojisi Açısından Suç ve Suç Korkusu, str. 401-411. Ankara, Hegem Yayınları.

Ferraro, K. F. (1995): Fear of crime: Interpreting victimization risk. Albany, State University of New York Press.

Ferraro, K. F., in LaGrange, R. L. (1987): The measurement of fear of crime, Sociological Inquiry, 57(1), str. 70-97.

DOI: :10.1111/j.1475-682x.1987.tb01181.x

Ferraro, K. F., in LaGrange, R. L. (1992): Are older people most afraid of crime? Reconsidering age differences in fear of victimization. Journal of Gerontology, 47(5), str. 233-244. DOI: 10.1093/geronj/47.5.s233

Foster, S., Giles-Corti, B., in Knuiman, M. (2010): Neighbourhood design and fear of crime: A social-ecological examination of the correlates of residents? Fear in new suburban housing developments. Health \& Place, 16(6), str. 1156-1165. DOI: 10.1016/j.healthplace.2010.07.007
Franklin, T. W., Franklin, C. A., in Fearn, N. E. (2008): A multilevel analysis of the vulnerability, disorder, and social integration models of fear of crime. Social Justice Research, 21(2), str. 204-227.

DOI: :10.1007/s11211-008-0069-9

Furstenberg, F. F., Jr. (1971): Public reaction to crime in the streets. The American Scholar, 40, str. 601-610.

Garofalo, J. (1981): The fear of crime: Causes and consequences. The Journal of Criminal Law and Criminology, 72(2), str. 839-857. DOI: $10.2307 / 1143018$

George, D., in Mallery, M. (2010): SPSS for Windows step by step: A simple guide and reference, 17.0 update (10th ed.). Boston, Pearson.

Gilchrist, E., Bannister, J., Ditton, J., in Farrall, S. (1998): Women and the "fear of crime": Challenging the accepted stereotype. The British Journal of Criminology, 38(2), str. 283-298.

DOI: 10.1093/oxfordjournals.bjc.a014236

Gray, E., Jackson, J., in Farrall, S. (2011): Feelings and functions in the fear of crime, applying a new approach to victimisation insecurity. British Journal of Criminology, 51, str. 75-94. DOI: 10.1093/bjc/azq066

Greene, M. (2003): Urban safety in residential areas: Spatial variables in crime and feeling of (in)security. Prispevek je bil predstavljen na konference iz naslovom World Bank Urban Research Symposium, ki je potekala od 15. do 17. decembra v Washingtonu, DC, v ZDA. Tipkopis.

Hale, C. (1993): Fear of crime: A review of the literature, report to the Metropolitan Police Service Working Party on the Fear of Crime. Raziskovalno poročilo. Canterbury, Canterbury Business School, University of Kent.

Internet 1: http://www.cumhuriyet.com.tr/haber/turkiye/607721/ Sort_giyen_kadina_tekme_atan_saldirganin_korkunc_sozleri_Kafasini_koparmak_lazim.html (sneto 3. 6. 2021).

Internet 2: http://www.cumhuriyet.com.tr/haber/turkiye/765079/Yine_ sortlu_kadina_saldiri Ramazan_da_boyle_giyinmeye_utanmiyor_musun_diyerek_yuzume_yumruk_atti.html (sneto 3. 6. 2021).

Internet 3: https://listelist.com/kadikoyde-yasama-nedenleri/ (sneto 8. 7. 2021)

Internet 4: https://www.indyturk.com (sneto 8. 7. 2021).

Internet 5: http://www.gazetekadikoy.com.tr/gundem/kiyafetime-sortuma-hayatima-karisma-h10956.html (sneto 2. 10. 2021).

Jackson, J. (2009): A psychological perspective on vulnerability in the fear of crime. Psychology, Crime \& Law, 15(4), str. 365-390. DOI: :10.1080/10683160802275797

Kalpana, V., in Ashish B. (2015): SafetiPin: An innovative mobile app to collect data on women's safety in Indian cities, Gender \& Development, 23(1), str. 45-60. DOI: 10.1080/13552074.2015.1013669

Karal, D., in Aydemir, E. (2012): Türkiye'de Kadına Yönelik Şiddet, USAK Sosyal Araştırmalar Merkezi Raporu 12-01. Raziskovalno poročilo. Ankara, Uluslararası Stratejik Araştırmalar Kurumu.

Kohm, S. A., Waid-Lindberg, A., Weinrath, M., Shelley, T. O. C., in Dobbs, R. R. (2012): The impact of media on fear of crime among university students: A cross-national comparison. Canadian Journal of Criminology and Criminal Justice 54, str. 67-100. DOI: 10.3138/cjccj.2011.E.01

Koskela, H. (1997): "Bold walk and breakings": Women's spatial confidence versus fear of violence. Gender, Place and Culture, 4, str. 301-319. DOI: 10.1080/09663699725369

Koskela, H. (1999): "Gendered exclusions": Women's fear of violence and changing relations to space. Geografiska Annaler: Series B, Human Geography, 81(2), str. 111-124. DOI: 10.1111/j.0435-3684.1999.00052.x

Kul, M. (2013): Suçtan Daha Büyük Suç Korkusu, İstanbul'da Bir Alan Araştırması. Istanbul, Yeniyüzyıl Yayınları. 
Lordoğlu, C. (2018): İstanbul'da Bekar Kadın Olmak. Istanbul, iletişim Yayınları.

Macmillan, R., Nierobisz, A., in Welsh, S. (2000): Experiencing the streets: Harassment and perceptions of safety among women. Journal of Research in Crime and Delinquency, 37, str. 306-322.

DOI: $10.1177 / 0022427800037003003$

Mirrlees-Black, C, Mayhew, P., in Percy, A. (1996): The 1996 British Crime Survey: England and Wales. London, Home Office.

Nasar, J. I., in Fisher, B. (1993): "Hot spots" of fear and crime: A multi-method investigation. Journal of Environmental Psychology, 13, str. 187-206. DOI: 10.1016/S0272-4944(05)80173-2

Newman, O. (1996): Creating defensible space. Washington, DC, Department of Housing and Urban Development, Office of Policy Development and Research.

Otis, M. D. (2007): Perceptions of victimization risk and fear of crime among lesbians and gay men. Journal of Interpersonal Violence, 22(2), str. 198-217. DOI: 10.1177/0886260506295346

Öztürk, M., Kocacık, F., in Gönültaș, M. (2016): Suç korkusu ve risk algısının toplumsal cinsiyet açısından incelenmesi. Journal of Human Sciences, 13(1), str. 1488-1502. DOI: 10.14687/ijhs.v13i1.3691

Pain, R. (1991): Space, sexual violence and social control: Integrating geographical and feminist analyses of women's fear of crime. Progress in Human Geography, 15, str. 415-431. DOI: 10.1177/030913259101500403

Pain, R. (2001): Gender, race, age and fear in the city. Urban Studies, 38(5-6), str. 899-913. DOI: 10.1080/00420980120046590

Pritschet, L., Powell, D., in Horne, Z. (2016): Marginally significant effects as evidence for hypotheses: Changing attitudes over four decades. Psychological Science, 27(7), str. 1036-1042. DOI: 10.1177/0956797616645672

Ravenscroft, N., Uzzell, D., in Leach, R. (2002): Danger ahead? The impact of fear of crime on people's recreational use of nonmotorised shared-use routes. Environment and Planning C: Government and Policy, 20, str. 741-756. DOI: $10.1068 / \mathrm{c} 24 \mathrm{~m}$

Ross, C. E. (1993): Fear of victimization and health. Journal of Quantitative Criminology, 9, str. 159-175. DOI: 10.1007/BF01071166

Ross, C. E., in Jang, S. J. (2000): Neighborhood disorder, fear, and mistrust: The buffering role of social ties with neighbors. American Journal of Community Psychology, 28, str. 401-420. DOI: 10.1023/A:1005137713332

Sacco, V. F. (1993): Social support and the fear of crime. Canadian Journal of Criminology, 35, str. 187-196. DOI: 10.3138/cjcrim.35.2.187

Sallan Gül, S., in Altındal, Y. (2015): Kadın Cinayetlerinin ve Suç Korkusunun Görseller Üzerinden Medyada Yeniden Üretimi: Radikal Gazetesi Örneği. V: Solak, A., in Solak, Ö. (ur.): Gündelik Hayat Sosyolojisi Açııından Suç ve Suç Korkusu, str. 536-557. Ankara, Hegem Yayınları.

Sandberg, L., in Rönnblom, M. (2013): Afraid and restricted vs bold and equal: Women's fear of violence and gender equality discourses in Sweden. European Journal of Women's Studies, 20(2), str. 189-203. DOI: $10.1177 / 1350506812463911$

Smolej, M., in Janne K. (2006): The relation between crime news and fear of violence. Journal of Scandinavian Studies in Criminology and Crime Prevention, 7(2), str. 211-227. DOI: 10.1080/14043850601002429

Sutton, R. M., Robinson B., in Farrall S. D. (2011): Gender, fear of crime, and self-presentation: An experimental investigation. Psychology, Crime \& Law, 17(5), str. 421-433. DOI: 10.1080/10683160903292261

Tandoğan, O., in Simsek Ilhan, B. (2016): Fear of crime in public spaces: From the view of women living in cities. Procedia Engineering, 161, str. 2011-2018. DOI: 10.1016/j.proeng.2016.08.795
Taylor, R. B., in Hale. M. (1986): Testing alternative models of fear of crime. Journal of Criminal Law and Criminology, 77, str. 151-189. DOI: $10.2307 / 1143593$

Tığlı, N. (2019): Türkiye'de Kadın Cinayetleri Raporu, 01.01.201631.12.2018. Raziskovalno poročilo. Ankara, TBMM Kadın Erkek Firsat Eşitliği Komisyonu Çalışması,

Treske, M., idr. (1990): Frauen Angst Rüume - ein Fotodokumentation. Frankfurt, AK Frauenraeume.

TÜiK (2016): İstatistiklerle Kadın Raporu. Research report. Ankara.

Uçan, A., idr. (2016): Türkiye'de Erkek Şiddetiyle Mücadele Mekanizmaları İzleme Raporu. Research report. Istanbul, Mor Çatı Yayınları.

Uludağ, Ş. (2010): Vatandaşların Suç Korku (Güvenlik Endişesi) Seviyesine Etki Eden Faktörler ve Alınabilecek Önlemler: Malatya Örneği. Polis Bilimleri Dergisi, 12(1), str. 1-28.

Valentine, G. (1989): The geography of women's fear. Area, 21(4), str. 385-390.

Valentine, G. (1992): Images of danger: Women's sources of information about the spatial distribution of male violence. Area, 24(1), str. 22-29.

Vrij, A., in Winkel, F. W. (1991): Characteristics of the built environment and fear of crime: A research note on interventions in unsafe locations. Deviant Behaviour, 12, str. 203-215.

DOI: 10.1080/01639625.1991.9967873

Ward, R. A., LaGory, M., in Sherman, S. R. (1990): Fear of crime among the elderly as person/environment interaction. The Sociological Quarterly, 27(3), str. 327-341. DOI: 10.1111/j.1533-8525.1986.tb00264.x

Warr, M. (1984): Fear of victimization: Why are women and the elderly more afraid? Social Science Quarterly, 65(3), str. 681-702.

Warr, M. (1990): Dangerous situations: Social context and fear of victimization. Social Forces, 68(3), str. 891-907. DOI: 10.2307/2579359

Yirmibeşoğlu, F., in Ergun, N. (2015): Fear of crime among women in the old city center of Istanbul. Current Urban Studies, 3(2), str. 161-174. DOI: 10.4236/cus.2015.32014 